\title{
The Status of Soldiers and Terrorists under the Geneva Conventions
}

\author{
John C. Yoo"
}

The recent scandal over the disturbing misconduct of several U.S. servicemen and women at the Abu Ghraib prison has triggered renewed international attention to U.S. policy under the 1949 Geneva Conventions. Some place the blame for the Geneva Convention violations at $\mathrm{Abu}$ Ghraib squarely upon the U.S. decision back in February, 2002, not to confer prisoner of war protection under the Third Geneva Convention ("GPW") 1 to Taliban and al Qaeda fighters detained by the United States. In a speech at New York University sponsored by MoveOn.org, the former Vice President, Al Gore, argued that "[w] hat happened at that prison, it is now clear, is not the result of random acts of a few bad apples. It was the natural consequence of the Bush administration policy."' Similarly, on the floor of the United States Senate the next week, Senator Edward Kennedy declared that "Saddam's torture chambers reopened under new management: U.S. management."

One important defect in these criticisms, however, is the fact that U.S. policy towards Iraq detainees differs dramatically from U.S. policy towards Taliban and al Qaeda detainees. ${ }^{4}$ From the very beginning of Operation Iraqi Freedom, it has been U.S. policy to extend the rights and privileges of prisoners of war under the Geneva Convention to Iraqi detainees-just as it was U.S. policy during Operation Desert Storm in 1991.5 By contrast, it has been U.S. policy not

Professor of Law, University of California at Berkeley School of Law (Boalt Hall) (on leave); Visiting Fellow, American Enterprise Institute; Deputy Assistant Attorney General, Office of Legal Counsel, United States Department of Justice, 2001-03. I thank the Boalt Hall Fund for financially supporting my research for this article, and Robert Delahunty, Sam Eistreicher, Jack Goldsmith, and Hays Parks for their helpful comments. The views expressed here are those of the author alone.

1 Geneva Convention (III) Relative to the Treatment of Prisoners of War, Aug. 12, 1949, 6 U.S.T. 3316, T.I.A.S. 3364 ("GPW").

2 Sara Kugler, Gore: Rumsfeld, Rice, Tenet Should Resign, AP, May 27, 2004.

3150 Cong. Rec. S6473 (statement of Sen. Kennedy) (June 4, 2004).

4 See also John Yoo, Tertorists Have No Geneva Rights, Wall St. J., May 26, 2004, at A16.

5 See, e.g., Transcript, CBS Face The Nation, Mar. 23, 2003, available at http://www.defenselink.mil/transcripts/2003/t03232003_t0323cbs.html (Secretary Donald Rumsfeld: Iraqi detainees are being "treated under the Geneva Convention"); Transcript, CNN Late Edition, Mar. 23, 2003, available at http://www.defenselink.mil/transcripts/2003/t03252003_t0323rcn.html (Rumsfeld: "we treat Iraqi prisoners according to the Geneva Convention"); Transcript, Secretary Rumsfeld Stakeout following CNN Interview, Mar. 23, 2003, available at http://www.defenselink.mil/transcripts/2003/t03232003_t0323sdnbestkoutcnn.html (Rumsfeld: "Traqi soldiers . . They're being treated according to the Geneva and AID conventions"); Transcript, DoD News Briefing with Assistant Secretary of 
to treat Taliban and al Qaeda detainees as prisoners of war subject to protection under the Geneva Convention. ${ }^{6}$

This paper outlines the legal case for denying Geneva Convention protection to Taliban and al Qaeda detainees. It explains why the United States concluded that members of the al Qaeda terrorist network and the Taliban militia are illegal combatants under the laws of war, and so cannot claim the legal protections and benefits that accrue to legal belligerents, such as prisoner of war status under the Third Geneva Convention.

This conclusion has several important consequences. First, from the perspective of U.S. national security, the Geneva Convention presents substantial obstacles to the effective acquisition of intelligence from the interrogation of detainees. Article 17 of the Convention provides that "[e]very prisoner of war, when questioned on the subject, is bound to give only his surname, first names and rank, date of birth, and army, regimental, personal or serial number, or failing this, equivalent information. . . . Prisoners of war who refuse to answer may not be threatened, insulted, or exposed to unpleasant or disadvantageous treatment of any kind." Interrogation methods routinely used at American police stations frequently include offers of leniency and special benefits for cooperating individuals. Article 17's prohibition on "disadvantageous treatment" means that prisoners of war are given even better treatment than that afforded to criminal suspects under U.S. law. In addition, the Geneva Convention provides a number of human comforts not guaranteed to criminal suspects under U.S. law. All humans are entitled to food, water, and basic shelter. Yet under Article 26, prisoners "shall, as far as possible, be associated with the preparation of their meals . . . they shall be given the means of preparing, themselves, the additional food in their possession." Article 26 also provides for the "use of tobacco." Article 38 guarantees access to "intellectual, educational, and recreational pursuits, sports and games," and the detaining power must "take the measures necessary" to "provid[e] them with adequate premises and necessary equipment." Detainees

Defense for Public Affairs Victoria Clarke and Major General Stanley A. McChrystal, Mar. 24, 2003, available at http://www.defenselink.mil/transcripts/2003/ t03242003_t0324asd.html (Clarke: "We are treating all of the [Iraqi] POWs in accordance with the Geneva Conventions"); see also Douglas J. Feith, Conventional Warfare, Wall St. J., May 24, 2004, at A14 "As to Iraq, the U.S. government has recognized from the outset that the Geneva Conventions apply by law and all Iraqi detainees are covered by them. All Iraqi military detainees have had POW status. As we all know from the horrible photos, some detainees in Iraq have been abused, but that mistreatment violated the Defense Department's policy as promulgated by the secretary."); Alberto Gozales, Terrorists Are Different, http://www.usatoday.com/ news/opinion/editorials/2004-06-09-oppose_x.htm.

( Press Briefing by Ari Fleischer, Feb. 7, 2002, available at www.whitehouse.gov/news/releases/2002/02/20020207-6.html; Katherine Q. Seelye, In Shift, Bush Says Geneva Rules Fit Taliban Captives, N.Y. Times, at A1 (Feb. 8, 2002). 
must be given "opportunities for taking physical exercise including sports and games and for being out of doors," and "[s]ufficient open space" must be provided for those purposes.

These rights are designed for professional soldiers who are duty-bound to fight for their nation-not for criminals, and certainly not for terrorists. Indeed, prisoners of war are also entitled to "working pay" (Article 54) and "a monthly advance of pay" (Article 60), as befitting professional soldiers captured in the line of duty. Not only are prisoners of war entitled to receive "relief shipments" from outsiders, those shipments are "exempt from import, customs and other dues" (Article 74).

The conclusion that unlawful combatants, including terrorist organizations and organizations that harbor them, are not subject to Geneva Convention protection also has other important consequences besides national security and the collection of life-saving military intelligence. The effective enforcement of international law, including the laws of war, requires the existence of incentives for compliance and disincentives for noncompliance. That includes prisoner of war protection for compliance with the laws of war, and denial of such protection to unlawful combatants. As Allan Rosas explained in his renowned 1976 treatise, The Legal Status of Prisoners of War: A Study in International Humanitarian Law Applicable in Armed Conflicts, "the only effective sanction against perfidious attacks in civilian dress is deprivation of prisoner-of-war status." 7 That is precisely why the Geneva Conventions extend prisoner of war protections only to lawful combatants. Indeed, as I explain below, President Ronald Reagan, supported by the State Department, refused to support the 1977 Protocol I Additional to the 1949 Geneva Conventions, specifically because that protocol was designed to do what the 1949 Convention did not-namely, extend rights and protections to unlawful combatants.

\section{I.}

Members of al Qaeda and the Taliban militia are not legally entitled to the battery of special rights and protections designed for professional soldiers.

As a threshold matter, al Qaeda is not even a nation-state, and as such cannot be a state party to the Geneva Conventions. Even if al Qaeda were capable of becoming a party to the treaties, it has not done so, nor has it ever declared an intention to accept their terms. Naturally, al Qaeda members cannot claim the benefits of a treaty to which their organization is not a party.

Those threshold issues aside, al Qaeda members fall within the category of

Allan Rosas, The Legal Status of Prisoners of War: A Study in International Humanitarian Law Applicable in Armed Conflicts 344 (1976). 
what are known as illegal combatants. Although the term "illegal combatant" is not expressly mentioned in the Geneva Conventions, it is a concept that has long been recognized by state practice in the law of war area. As the U.S. Supreme Court unanimously stated over 60 years ago, "[b]y universal agreement and practice the law of war draws a distinction between the armed forces and the peaceful populations of belligerent nations and also between those who are lawful and unlawful combatants." These two sets of distinctions each play a critical role in achieving the fundamental objective of the laws of war: to minimize the amount of human suffering and hardship necessitated by a state of war. ${ }^{9}$

The customary laws of war minimize human suffering in wartime by limiting the suffering and hardship of war, to the maximum extent possible, to the participating combatants, and by keeping military hostilities away from civilians. This approach naturally requires the effective enforcement of a sharp distinction between civilians and combatants. Accordingly, customary law demands that combatants respect the distinction between civilians and themselves by imposing a variety of prohibitions and requirements. Customary law forbids the intentional targeting of civilians, ${ }^{10}$ and encourages combatants to take measures to avoid unnecessary harm to civilians in their own military operations. ${ }^{11}$ Customary law

$8 \quad$ Ex parte Quirin, 317 U.S. 1, 30-31 (1942) (emphasis added).

g) See, e.g., W. Thomas Mallison \& Sally V. Mallison, The Juridical Status of Irregular Combatants under the International Humanitarian Law of Armed Conflict, 9 Case W. Res. J. Int'l L. 39, 43 (1977) ("overtiding, legal policy objective of the law of armed conflict is the minimization of the destruction of human and material values"); The Law of War on Land, being Part III of the Manual of Military Law 2 (Great Britain, War Office 1958) ("The law of war is inspired by the desire of all civilised nations to reduce the evils of war by ... protecting both combatants and non-combatants from unnecessary suffering").

10 See, e.g., Jean S. Pictet, ed., Commentary, III Geneva Convention Relative to the Treatment of Prisoners of War, at 61 (1960) ("GPW Commentary") (under the laws of war combatants "may not attack civilians or disarmed persons"); Jean S. Pictet, ed., Commentary, IV Geneva Convention Relative to the Protection of Civilian Persons In Time of War, at 3 (1958) ("GC Commentary") (noting the "cardinal principle of the law of war that military operations must be confined to the armed forces and that the civilian population must enjoy complete immunity"); Military Commissions, 11 Op. Att'y Gen. 297 (1865) ("[Under] the laws of war ... [n] on-combatants are not to be disturbed or interfered with by the armies of either party except in extreme cases."); Annotated Supplement to The Commander's Handbook on the Law of Naval Operations, at 5-10, NWP 9 (Rev. A), FMFM 1-10 (1989) ("it is forbidden to make noncombatants the object of attack"); Military Prosecutor v. Omar Mahmud Kassem and Others, 42 Int'l L. Rep. 470, 483 (1971) ("Immunity of non-combatants from direct attack is one of the basic rules of the international law of war.").

11 See, e.g., Lieber Code art. 19 ("Commanders, whenever admissible, inform the enemy of their intention to bombard a place, so that the noncombatants, and especially the women and children, may be removed before the bombardment commences."); id., art. 22 ("The principle has been more and more acknowledged that the unarmed 
also requires combatants to distinguish themselves from the civilian population in order to help enemy soldiers avoid doing harm to civilians. ${ }^{12}$ Naturally, in return for these various protections from hostilities, civilians are strictly forbidden under customary law from engaging in hostilities. The former cannot exist without the latter; combatants cannot fairly be told to refrain from using force against civilians if they regularly suffer attacks from such groups.

Al Qaeda violates the very core of the laws of war. Al Qaeda members are not under the control of a nation-state that will force them to obey the laws of war. They operate covertly by intentionally concealing themselves among the civilian population; they deliberately attempt to blur the lines between civilians and combatants. Most importantly, they have attacked purely civilian targets with the aim of inflicting massive civilian casualties. Thus, even if al Qaeda were a nation-state and a party to the Geneva Conventions, its members would still qualify as illegal belligerents due to their very conduct.

Unlike al Qaeda, the Taliban militia arguably constituted the de facto government troops of Afghanistan. Afghanistan is a party to the Geneva Conventions. Nonetheless, the Taliban militia, like al Qaeda, by their conduct did not meet the standards for legal belligerency that would have made its members legally entitled to prisoner of war status.

GPW entitles captured members of regular and irregular armed forces to the status of, and legal protections enjoyed by, POWs if they belong to units that meet the requirements of one of several applicable categories. GPW protections are available for members of militia under certain conditions. Article $4(\mathrm{~A})(1)$ extends POW status to "members of militias or volunteer corps forming part of" the "armed forces of a Party to the conflict."1.3 Article 4(A)(2) extends GPW protections to

$[\mathrm{m}]$ embers of other militias and members of other volunteer corps, including those of organized resistance movements, belonging to a Party to the conflict and operating in or outside their own territory, even if this territory is

citizen is to be spared in person, property, and honor as much as the exigencies of war will admit."); id., art. 23 ("the inoffensive individual is as little disturbed in his private relations as the commander of the hostile troops can afford to grant in the overruling demands of a vigorous war"); id., art. 25 ("protection of the inoffensive citizen of the hostile country is the rule").

12 See, e.g., Commentary on the Additional Protocols of 8 June 1977 to the Geneva Conventions of 12 August 1949, at 527 (1987) ("1977 Protocols Commentary") (noting "the fundamental rule that combatants are obliged to distinguish themselves from the civilian population while they are engaged in an attack or in a military operation preparatory to an attack"); R.C. Hingorani, Prisoners of War 48 (1982) ("It is one of the basic features of the laws of war that the combatants should be distinguished from non-combatants.").

136 U.S.T. 3320. 
occupied, provided that such militias or volunteer corps, including such organized resistance movements, fulfil the following conditions:

(a) that of being commanded by a person responsible for his subordinates;

(b) that of having a fixed distinctive sign recognizable at a distance;

(c) that of carrying arms openly;

(d) that of conducting their operations in accordance with the laws and customs of war. ${ }^{14}$

At best, it appears that Taliban fighters are members of a militia. The Central Intelligence Agency, for example, has recognized that Afghanistan has no national military, but rather a number of tribal militias factionalized among various groups. ${ }^{15}$ Thus, because members of the Taliban militia, like members of al Qaeda, do not comply with the four conditions of lawful combat expressly incorporated into article $4(\mathrm{~A})(2)$ of GPW, they are not entitled to the protections of that convention.

Even if the Taliban were able to claim status as a "regular armed force[," rather than as a militia, it still could not qualify for POW status under GPW article $4(\mathrm{~A})(1)$ or (3) without first satisfying the four customary conditions of lawful combat expressly enumerated in article 4(A)(2). Article 4(A)(1) extends POW status to " $[\mathrm{m}]$ embers of the armed forces of a Party to the conflict, as well as members of militias or volunteer corps forming part of such armed forces." 16 Article 4(A)(3) gives GPW protections to "[m]embers of regular armed forces who profess allegiance to a government or an authority not recognized by the Detaining Power."17 Unlike article 4(A)(2), the text of article 4(A)(1) and (3) does not expressly enumerate the four traditional conditions of lawful combat. Both provisions simply extend POW status to members of the regular "armed forces" of a party to the Convention.

It has long been understood, however, that regular, professional "armed forces" must comply with the four traditional conditions of lawful combat under the customary laws of war, and that the terms of article $4(A)(1)$ and (3) of GPW do not abrogate customary law. To facilitate compliance with, and enforcement of, the bedrock distinction between civilians and combatants, customary law

$14 \quad$ Id.

15 See Central Intelligence Agency, The World Factbook 2000, at 3 (complete entry for military branches of Afghanistan states: " $\mathrm{NA}$; note - the military does not exist on a national basis; some elements of the former Army, Air and Air Defense Forces, National Guard, Border Guard Forces, National Police Force (Sarandoi), and tribal militias still exist but are factionalized among the various groups"). See also www.bartleby.com/151/a116.html (listing similar entry in 2001 edition of CIA Factbook).

16 6 U.S.T. 3320.

17 Id. 
developed these four basic conditions of lawful combatantcy that all regular fighters must meet. Those conditions of customary law were later spelled out in a written text, when delegates at an 1874 Conference in Brussels drafted a declaration stating the four conditions as follows: (1) "[t]hat they have at their head a person responsible for his subordinates," (2) "[ $t$ ] hat they wear some fixed distinctive badge recognizable at a distance," (3) "[t]hat they carry arms openly," and (4) "[t]hat in their operations they conform to the laws and customs of war."18 As recently noted by a federal district court, these "four criteria [which] an organization must meet for its members to qualify for lawful combatant status" were originally "established under customary international law" and "were first codified in large part in the Brussels Declaration of 1874."1" Commentators have similarly noted that article 9 of the Brussels Declaration was "merely declaratory of the existing customary law ... applicable to regulars." 20

The four conditions under customary law play an essential role in enforcing the fundamental distinction between civilians and combatants. The second and third conditions are practical provisions to help soldiers recognize the distinction between members of enemy forces and civilians during the conduct of military operations. ${ }^{21}$ The first and fourth conditions help ensure that the substantive rules of conduct respecting this fundamental distinction, such as the prohibition on targeting of civilians and the requirement of distinguishing oneself as a combatant, are effectively enforced.22

Taken together, these four conditions, aimed at facilitating the bedrock customary distinction between combatants and civilians, also establish a second

18 Translation of the Draft of an International Declaration concerning the Laws and Customs of War adopted by the Conference of Brussels, 27th August, 1874, art. 9, reprinted in A. Pearce Higgins, The Hague Peace Conferences and Other International Conferences Concerning the Laws and Usages of War: Texts of Conventions with Commentaries 274 (1909).

19 Lindh, 212 F. Supp. 2 d at $557 \&$ n.34.

20 Mallison \& Mallison, 9 Case W. Res. J. Int'l L. at 44. See also Jean S. Pictet, ed., Commentary, III Geneva Convention Relative to the Treatment of Prisoners of War, at 47 n.1 (1960) ("GPW Commentary") (Brussels Declaration "was the first international instrument specifying the customs of war").

21 See, e.g., Allan Rosas, The Legal Status of Prisoners of War: A Study in International Humanitarian Law Applicable in Armed Conflicts 341 (1976) (stating that purpose of these two conditions is "the need to protect the civilian population from attack and to ensure a certain fairness in fighting"). For an analysis of how these requirements of lawful combat apply to U.S. Special Forces, see W. Hays Parks, Special Forces' Wear of Non-Standard Uniforms, 4 Chicago J. Int'l L. 493 (2003).

22 See, e.g., U.S. Department of the Navy, Office of the Judge Advocate General, Annotated Supplement to The Commander's Handbook on the Law of Naval Operations, at 11-13 n.49, NWP 9 (Rev. A), FMFM 1-10 (1989) (purpose of four conditions of lawful combatantcy is to reduce "risk to the civilian population within which [some forces would otherwise] often attempt to hide"). 
fundamental distinction under customary law, that between lawful and unlawful combatants. Only lawful combatants - that is, members of fighting units that comply with all four conditions - are licensed to engage in military hostilities. ${ }^{23}$ The customary laws of war immunize only lawful combatants from prosecution for committing acts that would otherwise be criminal under domestic or international law.24 And only those combatants who comply with the four

23 See, e.g., Military Commissions, 11 Op. Att'y Gen. 297 (1865) ("The laws of war demand that a man shall not take human life except under a license from his government; and under the Constitution of the United States no license can be given by any department of the Government to take human life in war, except according to the law and usages of war. Soldiers regularly in the service have the license of the government to deprive men, the active enemies of the government, of their liberty and lives ... ."); Mallison \& Mallison, 9 Case W. Res. J. Int'l L. at 41 ("both regular and irregular combatants who comply with the legal criteria, including the central criterion of adherence to the laws and customs of war, are entitled to exercise controlled violence while they are militarily effective"); Michael Bothe, Karl Josef Partsch \& Waldemar Solf, New Rules for Victims of Armed Conflicts: Commentary on the Two 1977 Protocols Additional to the Geneva Conventions of 1949 at 232, 234-35 (1982) ("Members of the armed forces of a Party to a conflict . . . are combatants, that is to say, they have the right to participate directly in hostilities. . . [R] egular armed forces are inherently organized, . . . are commanded by a person responsible for his subordinates and . . are obliged under international law to conduct their operations in accordance with the laws and customs of war."); Kassem, 42 Int'l L. Rep. at 480 (" Only members of the armed forces have the right to engage in the actual fighting, that is, to kill, would or otherwise disable members of the opposing armed forces.") (quotations omitted).

2.4 See, e.g., Lindh, 212 F. Supp. 2d at 553-54 ("Lawful combatant immunity, a doctrine rooted in the customary international law of war, forbids prosecution of soldiers for their lawful belligerent acts committed during the course of armed conflicts against legitimate military targets. . . Importantly, this lawful combatant immunity is not automatically available to anyone who takes up arms in a conflict. Rather, it is generally accepted that this immunity can be invoked only by members of regular or irregular armed forces who fight on behalf of a state and comply with the requirements for lawful combatants."); see also Dow v. Johnson, 100 U.S. 158, 165 (1879) ("When . . . our armies marched into the country which acknowledged the authority of the Confederate government, that is, into the enemy's country, their officers and soldiers were not subject to its laws, nor amenable to its tribunals for their acts. They were subject only to their own government, and only by its laws, administered by its authority, could they be called to account."); Freeland v. Williams, 131 U.S. 405, 416 (1889) ("for an act done in accordance with the usages of civilized warfare under and by military authority of either party, no civil liability attached to the officers or soldiers who acted under such authority"); Lieber Code art. 57 ("So soon as a man is armed by a sovereign government and takes the soldier's oath of fidelity, he is a belligerent; his killing, wounding, or other warlike acts are not individual crimes or offenses."); Waldemar A. Solf \& Edward R. Cummings, A Survey of Penal Sanctions Under Protocol I to the Geneva Conventions of August 12, 1949, 9 Case 
conditions are entitled to the protections afforded to captured prisoners of war under the laws and usages of war. ${ }^{25}$ Indeed, denial of protected status under the laws of war has been recognized as an effective method of encouraging combatants to comply with the four conditions. ${ }^{26}$ Unlike lawful combatants, unlawful combatants have no right to engage in hostilities and enjoy no immunity from prosecution for their military activities, ${ }^{27}$ nor do they receive the protections afforded under the laws of war to captured prisoners of war.28 And of course, unlawful combatants-unlike civilians, and like combatants-are vulnerable to direct attack and targeted military hostilities, ${ }^{29}$ as common sense would clearly dictate. ${ }^{30}$

Customary law requires combatants to respect the distinction between civilians and combatants, and mandates that combatants comply with the four

W. Res. J. Int'l L. 205, 212 (1977); James W. Garner, Punishment of Offenders Against the Laws and Customs of War, 14 Am. J. Int'l L. 70, 73 (1920).

25 See Mallison \& Mallison, 9 Case W. Res. J. Int'l L. at 41 (only "combatants who comply with the legal criteria ... have the legally privileged status of prisoners of war ... upon capture").

26 See, e.g., Rosas, $n .7$ above, at 344 ("the only effective sanction against perfidious attacks in civilian dress is deprivation of prisoner-of-war status").

27 See Quirin, 317 U.S. at 31 ("Unlawful combatants are . . are subject to trial and punishment by military tribunals for acts which render their belligerency unlawful."); Lindh, 212 F. Supp. 2d at 554 ("only [lawful combatants are] eligible for immunity from prosecution"); Allan Rosas, n.7 above, 419 (1976) ("persons who are not entitled to prisoner-of-war status are as a rule regarded as unlawful combatants, and can thus be prosecuted for the mere fact of having participated in hostilities"); Gregory M. Travalio, Terrorism, International Law, and the Use of Military Force, 18 Wis. Int'l L.J. 145, 184-85 (2000) ("Furthermore, because the terrorists would not qualify under Article 4 of Geneva Convention III as Prisoners of War, they would not have immunity for their actions. They could, therefore, be charged with crimes such as murder, assault, and others."); Kassem, 42 Int'l L. Rep. at 480 (describing the "rights and obligations of civilians" as the right "not to be intentionally killed and wounded" and the obligation "not to kill and wound") (quotations omitted); id. (" $\rceil \mathrm{t}$ is a serious offense, in some cases punishable by death, for a person who does not belong to the armed forces unlawfully to assume the quality of combatant."').

28 See Ingrid Detter, The Law of War 148 (2d ed. 2000) ("Unlawful combatants . . are not, if captured, entitled to any prisoner of war status.").

29 See id. at 148 ("Unlawful combatants . . . are a legitimate target for any belligerent action ....").

30 It has been contended by some that unlawful combatants, if not protected under GPW, are entitled to the rights guaranteed under GC, even though the very title of that convention indicates that it protects only "civilians." I find this contention absurd; taken to its logical conclusion, it would actually forbid lawful combatants, for example, from conducting military hostilities against unlawful combatants, pursuant to the requirements of GC article 27, which forbids "all acts of violence or threats thereof" against persons covered by GC, whether or not they are held in custody. 
conditions of lawful combat as a condition of their status as legitimate belligerents entitled to engage in war on behalf of their sovereign. When various efforts were initiated, beginning in 1874, to codify customary law into written form, drafters saw no need to enumerate the four conditions with respect to regular, professional armies; those were already provided for under customary law. Explicit reference to the four conditions was necessary only in order to achieve certain innovations in the laws of war: namely, to extend the rights and duties of lawful combatants beyond fighters in regular armies, to include members of militia, volunteer corps, and other irregular forces. ${ }^{31}$ The four customary conditions of lawful combat were codified into a legally binding treaty for the first time in 1899, when the First Hague Peace Conference drafted article 1 of the Hague Convention Annex. Ratified by the United States in 1902,32 the 1899 Hague Convention constitutes the first multilateral attempt to legislate in this area. ${ }^{33}$ This successful effort to establish binding international law governing the treatment of prisoners of war, like subsequent efforts, tracked closely the text of article 9 of the Brussels Declaration, both with respect to its express application of the four conditions of lawful combat to irregular forces, and its implicit incorporation of the customary legal principle that all regular forces by definition must satisfy precisely those same four conditions. The 1907 version of the Hague Convention reflects the same approach.

It would not be long before new international texts would be introduced to govern the laws of war, given the inherent weaknesses of the 1899 and 1907 Hague Conventions. Those two conventions required state parties merely to instruct their armed forces of the principles articulated in the Annex, including the four customary conditions of lawful combat enumerated in article 1 . The four conditions were finally given full legal force in 1929, when a Diplomatic Conference held that year in Geneva drafted an entirely new set of protections for POWs. Ratified by the United States in 1932, the Geneva Convention Relative to

31 See, e.g., Mallison \& Mallison, 9 Case W. Res. J. Int'l L. at 44 ('The new juridical concept is the provision which applies the same rights and obligations to militia and volunteers if they comply with the specified four conditions").

32 The Senate gave its advice and consent to ratification on March 14, 1902. See 35 Cong. Rec. 2792 (1902). The President soon ratified the convention on March 19, 32 Stat. 1803, and proclaimed the convention on April 11, 32 Stat. 1826.

33 See GPW Commentary at 4 ("it was not until the Peace Conferences of 1899 and 1907 that States first agreed to limit as between themselves their sovereign rights over prisoners of war"); id. at 46 (explaining that it was not until "the Hague Convention of 1899 . . before prisoners were granted their own statute in international law"); see also Howard S. Levie, Enforcing The Third Geneva Convention On The Humanitarian Treatment of Prisoners of War, 7 U.S. Air Force Academy J. of Legal Stud. 37 (1997), reprinted in Michael N. Schmitt \& Leslie C. Green, eds., Levie on the Law of War, 70 Int'l Legal Stud. 459 (Naval War College 1998). 
the Treatment of Prisoners of War ("1929 GPW") 34 itself did not articulate the four conditions. It instead incorporated by reference the categories of protected persons contained in article 1 of the 1907 Hague Convention Annex. ${ }^{35}$ Thus, like the 1899 and 1907 Hague Conventions, the 1929 GPW did not explicitly require armies to comply with the four traditional conditions of lawful combat. Once again, however, there was no indication that the drafters intended to abrogate customary law, under which armies had long been required to meet those conditions. To the contrary, all of these agreements tracked closely article 9 of the 1874 Brussels Declaration. As previously noted, article 9 was well understood to maintain the customary rule that regular armies must comply with the four conditions of lawful combat, even though that article did not explicitly say so. That same customary rule was also preserved in the 1899 and 1907 Hague Conventions and the 1929 GPW.

Many provisions of GPW were drafted to provide more generous rights and protections to POWs than those afforded under earlier conventions governing the conduct of war and the treatment of prisoners of war. But there is no indication that the drafters intended GPW to abrogate the customary rule that regular armies must satisfy the four traditional conditions of lawful combat in order to enjoy the protections afforded by the laws of war. To the contrary, article 4 of GPW, governing eligibility for international legal protection, was drafted "in harmony" with customary legal principles embodied in the Hague Regulations, not to rescind or abrogate them. ${ }^{36}$

The drafters of GPW held two basic understandings in common with their predecessors. First, under customary law, organized armed forces were already required to satisfy the four conditions of lawful combat. There was accordingly

July 27, 1929, 47 Stat. 2021.

47 Stat. 2030.

GPW Commentary at 49 " Article $4 \ldots$ was discussed at great length during the 1949 Diplomatic Conference and there was unanimous agreement that the categories of persons to whom the Convention is applicable must be defined, in harmony with the Hague Regulations."). See also id. at 5 ("The [1929] Convention was closely related to the Hague Regulations, since prisoner-of-war status depended on the definition of a belligerent as stipulated in Articles 1,2 and 3 of those Regulations. Thus neither the 1929 Convention, nor indeed the present [1949] Convention, rescinded the Hague Regulations . . .."); id. at 51 ("Article 4 is independent from the laws and customs of war as defined in the Hague Conventions, but there was never any question when the Convention was drafted of abrogating the Hague law. In other words, the present Convention is not limited by the Hague Regulations nor does it abrogate them, and cases which are not covered by the text of this Convention are nevertheless protected by the general principles declared in 1907."); S. Exec. Rep. No. 9, 84th Cong., 1st Sess., at 5 (1955) (GPW article 4 "does not change the basic principle" of the 1907 Hague Convention). 
no need for article 4 to apply those conditions explicitly to such regular forces. ${ }^{37}$ By contrast, there was a perceived need to continue to state expressly that irregular forces must comply with those conditions to trigger the protections afforded to POWs, as was stated in earlier codifications of the laws of war. The drafters of GPW thus explicitly enumerated the four conditions of lawful combat only in the text of article $4(A)(2)$, using language virtually identical to that of the Hague Regulations. ${ }^{38}$ The provisions of GPW respecting the legal status of legitimate combatants thus track closely those of its predecessors. As previously explained, article 4(A)(2) expressly enumerates the four conditions with respect to irregular forces, such as militias and volunteers corps, not forming a part of a regular armed force of a party.3' Those four conditions do not appear, by contrast, in either article $4(A)(1)$ or (3), the provisions governing regular armed forces.40 However, like the Brussels Declaration, the two Hague Conventions, and the $1929 \mathrm{GPW}$, there is no indication that article 4 of GPW was drafted to abrogate the long established customary rule that regular forces by definition must comply with the four conditions to enjoy the legal status of legitimate combatants under the laws of war.

II.

Subsequent international developments respecting the Geneva Conventions

37 See, e.g., GPW Commentary at 63 "The delegates to the 1949 Diplomatic Conference were ... fully justified in considering that there was no need to specify for ... armed forces the requirements stated in sub-paragraph (2) (a), (b), (c) and (d).").

35 See GPW Commentary at 56 ("The ... text [of article 4(A)(2)] corresponded to that in the Hague Regulations, since the conditions specified in (a), (b), (c), (d), were identical."); id. at 58 ("the four conditions contained in sub-paragraphs (a) to (d) are identical with those stated in the Regulations"); id. at 59 (same).

39) See GPW art. 4(A)(2), 6 U.S.T. 3320 (extending POW status to "[m]embers of other militias and members of other volunteer corps, including those of organized resistance movements, belonging to a Party to the conflict and operating in or outside their own territory, even if this territory is occupied, provided that such militias or volunteer corps, including such organized resistance movements, fulfil the following conditions: (a) that of being commanded by a person responsible for his subordinates; (b) that of having a fixed distinctive sign recognizable at a distance; (c) that of carrying arms openly; (d) that of conducting their operations in accordance with the laws and customs of war").

40 See GPW art. 4(A)(1), 6 U.S.T. 3320 (extending POW status to "[m]embers of the armed forces of a Party to the conflict, as well as members of militias or volunteer corps forming part of such armed forces"); GPW art. 4(A)(3), 6 U.S.T. 3320 (extending POW status to " $[\mathrm{m}]$ embers of regular armed forces who profess allegiance to a government or an authority not recognized by the Detaining Power"). 
confirm that there exists a category of combatants under GPW who are not required to comply with the four customary conditions of lawful combatantcy.

Specifically, in 1977, delegates from various nations drafted two protocols to the 1949 Geneva Conventions. One of the primary purposes of Protocol I Additional to the 1949 Geneva Conventions was to expand the categories of individuals who would be protected under any of the four original 1949 Geneva Conventions. Article 44(3) of Protocol I, for example, would significantly dilute the traditional requirement under customary law and GPW that combatants must distinguish themselves from civilians and otherwise comply with the laws of war as a condition of protection under the Geneva Conventions. Specifically, that provision provides as follows:

In order to promote the protection of the civilian population from the effects of hostilities, combatants are obliged to distinguish themselves from the civilian population while they are engaged in an attack or in a military operation preparatory to an attack. Recognizing, however, that there are situations in armed conflicts where, owing to the nature of the hostilities an armed combatant cannot so distinguish himself, he shall retain his status as a combatant, provided that, in such situations, he carries his arms openly:

(a) during each military engagement, and

(b) during such time as he is visible to the adversary while he is engaged in a military deployment preceding the launching of an attack in which he is to participate. ${ }^{+1}$

The Reagan Administration opposed this provision and refused to submit the first protocol to the Senate for its consideration, precisely because it opposed the idea of diluting the customary rule that combatants must comply with all four traditional conditions of lawful combatantcy. As he explained to the Senate, President Reagan opposed Protocol I, in part, because it

would grant combatant status to irregular forces even if they do not satisfy the traditional requirements to distinguish themselves from the civilian population and otherwise comply with the laws of war. This would endanger civilians among whom terrorists and other irregulars attempt to conceal themselves. These problems are so fundamental in character that they cannot be remedied through reservations, and I therefore have decided not to submit the Protocol to the Senate in any form . . . . [W] must not, and need not, give recognition and protection to terrorist groups as a price for progress in humanitarian law. ${ }^{42}$

41 Commentary on the Additional Protocols of 8 June 1977 to the Geneva Conventions of 12 August 1949, at 519 (1987) ("1977 Protocols Commentary").

42 S. Treaty Doc. 100-2, 100th Cong., 1st Sess., at 4 (1987). 
The State Department likewise opposed ratification of Protocol I, noting that

Article 44(3), in a single subordinate clause, sweeps away years of law by "recognizing" that an armed irregular "cannot" always distinguish himself from non-combatants; it would grant combatant status to such an irregular anyway. As the essence of terrorist criminality is the obliteration of the distinction between combatants and non-combatants, it would be hard to square ratification of this Protocol with the United States' announced policy of combatting [sic] terrorism. ${ }^{43}$

As Abraham D. Sofaer, then the State Department's Legal Adviser, wrote at the time:

Article 44 of Protocol I . . allows irregular fighters to retain combatant and POW rights even though they do not comply with the traditional requirement of distinguishing themselves from the civilian population by carrying their arms openly and wearing some distinctive sign. (The only exception would be during attacks and military operations preparatory to an attack.) This provision would make it easier for irregulars to operate, and it would substantially increase the risks to the civilian population. Inevitably, regular forces would treat civilians more harshly and with less restraint if they believed that their opponents were free to pose as civilians while retaining their right to act as combatants and their POW status if captured. Innocent civilians would therefore be made more vulnerable by application of the Protocol. This is no advance for humanitarian law.

In addition, the Protocol eliminates one of the basic existing requirements that irregular groups must meet to qualify for combatant and POW status: that the group as such generally conduct its operations in accordance with the laws and customs of war. Instead, Protocol I provides that individual members of such groups must be accorded POW benefits (with very limited exceptions) even if the group as such (e.g., the PLO) displays a callous and systematic disregard for the law. This means in effect that liberation groups can enjoy many of the benefits of the law of war without fulfilling its duties, and with the confidence that the belligerent state has no real remedy under the Protocol to deal with this matter. ${ }^{44}$

In short, "[t]reating . . terrorists as soldiers . . enhances their stature, to the detriment of the civilized world community." 45

A 1989 Department of the Navy publication similarly explains that,

43 Id. at 9.

44 Abraham D. Sofaer, Agora: The U.S. Decisions Not to Ratify Protocol I to the Geneva Conventions on the Protection of War Victims (Cont'd): The Rationale for the United States Decision, 82 Am. J. Int'l L. 784, 786 (1988). 
"[p]erhaps more than any other provision, [Article 44(3)] is the most militarily objectionable to the United States because of the increased risk to the civilian population within which such irregulars often attempt to hide."46 Commentators have made similar observations about the 1977 Protocol I. Most notably, Professor Howard S. Levie has noted that,

[b]ecause irregular troops, particularly members of national liberation movements, rarely meet the requirements of [GPW Article 4(A)(2)], a strong movement surfaced early at the first session of the 1977 Diplomatic Conference with the objective of legislating protection for these individuals under practically any circumstances. . . Unquestionably, the intent [of Article 44] was to ensure that captured members of national liberation movements would fall within the definition of prisoners of war, whatever their prior conduct may have been. ${ }^{47}$

The specific grounds of opposition to article 44(3) of Protocol I by the United States thus further demonstrate that, under GPW, all combatants must comply with the four conditions expressly enumerated in article 4(A)(2) in order to enjoy the Convention's protections.

This is not the place to discuss whether the United States had the factual basis upon which to decide whether the Taliban militia actually met the four criteria for legal belligerency. It is enough at this point to conclude that President Bush had the legal basis to conclude that the Taliban militia had to meet those four criteria in order to be legally entitled to the status of legal belligerency, and, as a result, the protections accorded to prisoners of war under the Geneva Convention.

There are important distinctions between prisoners of war and terrorists. It is because professional soldiers comply with the laws of war, and are members of fighting units with organizational hierarchies and disciplinary systems that are designed to enforce such compliance, that they are entitled to the rights and protections of prisoners of war under the Geneva Conventions. And it is

$45 \quad$ Id.

46 U.S. Department of the Navy, Office of the Judge Advocate General, Annotated Supplement to The Commander's Handbook on the Law of Naval Operations, at 1113 n.49, NWP 9 (Rev. A), FMFM 1-10 (1989).

47 Howard S. Levie, 1 The Code of International Armed Conflict 13 (1986) (emphasis added). See also Rosas, n. 7 above, at 327 ("draft Protocol I submitted by the ICRC . . is an attempt to loosen the four classical conditions"). 
precisely because terrorists violate fundamental international legal norms by targeting civilians for violence that the Geneva Conventions deprive them of such rights and protections. To ignore these fundamental distinctions poses a threat to U.S. national security and undermines the very purpose and function of international humanitarian law. 